\title{
Unjuk Kerja IP PBX Asterisk dan FreeSWITCH pada Topologi Bertingkat di Jaringan Kampus
}

\author{
Iwan Setiawan ${ }^{1}$, Azis Wisnu Widhi Nugraha ${ }^{2}$, Adi Septian Putra Atmaja ${ }^{3}$ \\ 1,2,3 Jurusan Teknik Elektro, Fakultas Teknik, Universitas Jenderal Soedirman \\ Jl. Mayjend. Sungkono km 5, Kalimanah 53371, Purbalingga, Indonesia \\ Email korespondensi : stwn@unsoed.ac.id
}

Dikirim 19 April 2017, Direvisi 06 Mei 2017, Diterima 26 Juli 2017

\begin{abstract}
Abstrak - Internet Protocol-based Private Branch Exchange (IP PBX) diperlukan untuk menghubungkan panggilan antar perangkat komunikasi Voice over Internet Protocol (VoIP) di sebuah jaringan lokal (LAN). Dengan adanya IP PBX, layanan VoIP dapat disediakan di atas jaringan data/IP yang sudah tergelar. Penelitian ini dilakukan untuk mengetahui unjuk kerja VoIP pada dua IP PBX yang menggunakan perangkat lunak server Asterisk dan FreeSWITCH. Kami merancang sebuah arsitektur jaringan eksperimen yang diadaptasi dari topologi bertingkat pada jaringan kampus (CAN) di lokasi penelitian dengan hierarki perangkat yang terdiri dari core switch, distribution switch, dan access switch. Kedua IP PBX ditempatkan pada hierarki yang berbeda pada topologi jaringan tersebut agar dapat diketahui pengaruhnya terhadap unjuk kerja VoIP. Konsep eksperimen ini diharapkan dapat menjadi salah satu dasar untuk mendesain arsitektur IP PBX secara terpusat dan tersebar pada jaringan kampus. Unjuk kerja VoIP diukur dengan parameter-parameter Quality of Service (QoS) dan Quality of Experience (QoE). Selain itu, dimonitor juga konsumsi prosesor dan memori yang dipakai oleh perangkat lunak server VoIP pada saat komunikasi terjadi. Pengukuran dilakukan dengan skenario phone-to-phone pada jaringan eksperimen yang terhubung ke jaringan kampus aktif. Hasil penelitian menunjukkan bahwa penempatan IP PBX di hierarki yang berbeda pada topologi jaringan berpengaruh terhadap unjuk kerja VoIP khususnya pada IP PBX Asterisk. Ketika dibandingkan, unjuk kerja IP PBX FreeSWITCH dalam hal QoS dan QoE sedikit lebih baik daripada Asterisk pada rerata latensi/delay, jitter, Mean Opinion Score (MOS), dan konsumsi memori yaitu 41,012 ms, 0,060 ms, 5, dan $1 \%$ untuk IP PBX 1 serta 41,016 ms, 0,066 ms, 5, dan 0,5\% untuk IP PBX 2.
\end{abstract}

Kata kunci - Asterisk, FreeSWITCH, IP PBX, unjuk kerja VoIP, topologi bertingkat, jaringan kampus

Abstract - Internet Protocol-based Private Branch Exchange (IP PBX) is needed to interconnect/switch calls between VoIP communication devices in a Local Area Network (LAN). VoIP service can be provided by using IP PBX in data/IP networks that are already provisioned. This research conducted to evaluate VoIP performances of two IP PBX using Asterisk and FreeSWITCH. We design an experimental network architecture that is adapted from the hierarchical topology in a Campus Area Network (CAN) at the research location that consists of core switch, distribution switch, and an access switch. The two IP PBXs are placed at different locations in the hierarchy of the network topology for investigating the effects of the placement to the VoIP performance. This experimental concept can be used as a base for designing architectures of centralized and distributed IP PBX in the campus network. We measure VoIP performance by evaluating the systems with the Quality of Service (QoS) and the Quality of Experience (QoE) parameters. We also monitor processor and memory consumptions that are used by each VoIP server software when communication takes place. The evaluation was conducted on VoIP system with a phone-to-phone scenario in the experimental network that is connected to the active campus network. Our results show that IP PBX placement at the different hierarchy of the network topology affects the VoIP performance, particularly on Asterisk IP PBX. The performance of FreeSWITCH IP PBX in terms of QoS and QoE is slightly better than the Asterisk one on average latency/delay, jitter, Mean Opinion Score (MOS), and memory consumption. The values are 41,012 ms, 0,060 ms, 5, $1 \%$ for IP PBX 1, and 41,016 ms, 0,066 ms, 5, 0,5\% for IP PBX 2.

Keywords - Asterisk, FreeSWITCH, IP PBX, VoIP performance, hierarchical topology, campus network 


\section{PENDAHULUAN}

Dengan semakin luasnya jaringan berbasis IP atau jaringan data dengan skala terbatas seperti jaringan lokal atau Local Area Network (LAN) sampai dengan yang lebih luas seperti Wide Area Network (WAN) dan Internet, ditambah dengan peningkatan jumlah pengguna serta pengembangan teknologi, menjadikan jaringan ini menarik dan potensial untuk digunakan sebagai infrastruktur komunikasi suara [1]. Konektivitas dan kapasitas bandwidth jaringan yang juga semakin hari semakin meningkat memunculkan potensi untuk penambahan dan variasi layanan seperti komunikasi multimedia.

VoIP sebagai layanan komunikasi di atas jaringan IP terus berkembang dalam bentuk beragam aplikasi yang memudahkan masyarakat untuk berkomunikasi khususnya komunikasi suara. Salah satu keunggulan dari komunikasi ini adalah biaya yang rendah jika dibandingkan dengan komunikasi yang memakai jaringan telepon tradisional, khususnya pada panggilan jarak jauh [2], [3]. Namun, layanan ini memiliki tantangan terbesar yaitu pada kualitas suara [1]-[3].

Jaringan IP menggunakan model layanan best effort. Dengan model ini, jaringan akan berusaha semaksimal mungkin mengantarkan paket data (datagram) dari sumber ke tujuan namun tidak memberikan jaminan bahwa paket tersebut akan sampai dalam waktu tertentu dan tidak hilang/loss [4]. Hal ini menjadi masalah pada komunikasi real-time seperti VoIP yang dapat berimbas pada informasi yang tidak sampai, waktu tunda atau latensi pada komunikasi, dan percakapan yang tidak jelas atau hilang. Untuk itu dibutuhkan kendali QoS end-to-end pada sistem VoIP untuk mempertahankan kualitasnya [1]-[6]. Elemen end-to-end pada sistem VoIP [2], [5] dari pengirim ke penerima secara umum dapat dilihat pada Gambar 1.

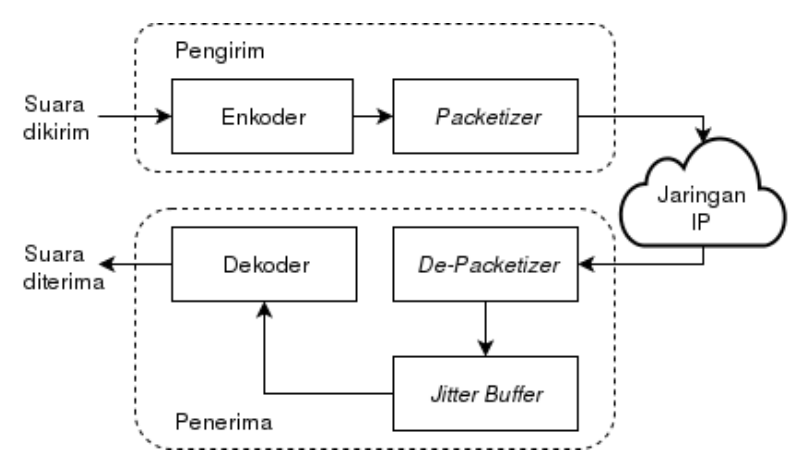

Gambar 1. Elemen End-To-End Pada Sistem VoIP

QoS dapat diukur dengan parameter unjuk kerja jaringan yaitu waktu tunda/latensi paket dari ujung sumber ke ujung tujuan atau end-to-end delay, variasi delay atau jitter, dan jumlah paket yang hilang atau packet loss [1]-[6], serta QoS subjektif atau dikenal dengan QoE yang berdasar pada penilaian persepsi pengguna secara subjektif terhadap kualitas layanan komunikasi [1]-[3], [5], [6]. Pengukuran QoS dan QoE dilakukan dengan memastikan supaya nilai-nilai parameternya sesuai standar seperti ITU-T G.114 [7], G.1010 [8], dan P.800 [9].

Untuk dapat memakai sistem komunikasi VoIP di jaringan lokal dibutuhkan IP PBX yang berfungsi untuk menghubungkan panggilan antar perangkat komunikasi di jaringan tersebut. Kumpulan jaringan lokal (LAN) yang saling terhubung serta umumnya menghubungkan banyak gedung dan tersebar pada beberapa lokasi dan sebagian dapat terpisah secara geografis sering disebut dengan jaringan kampus atau Campus Area Network (CAN). Jaringan kampus ini, yang umumnya dihubungkan oleh sebuah jaringan tulang punggung (backbone network) seperti di Unsoed, dapat menyediakan sistem komunikasi VoIP dengan memanfaatkan jaringan IP yang sudah tergelar. Hal ini akan meningkatkan utilitas jaringan dan efisiensi sumber daya termasuk infrastruktur komunikasi serta biaya.

Jaringan kampus Unsoed memiliki kapasitas besar dengan media pada jaringan tulang punggung berupa serat optik yang menghubungkan unit dan fakultas yang berada di wilayah Purwokerto dan Purbalingga. Gambaran umum topologi jaringan kampus Unsoed dapat dilihat pada Gambar 2. Topologi ini terdiri dari dua perangkat core switch yang berada di Grendeng, Purwokerto dan Blater, Purbalingga, sejumlah distribution switch di bawah core switch yang tersebar di unit-unit, dan pada hierarki paling bawah terdapat access switch yang menghubungkan perangkatperangkat pengguna.

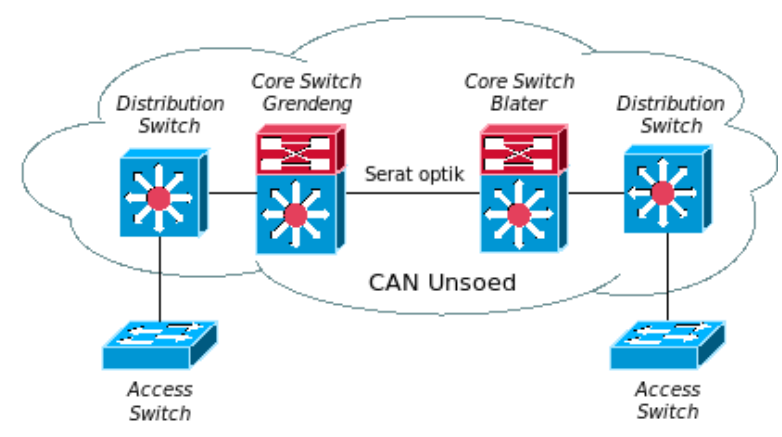

Gambar 2. Gambaran Umum Topologi Jaringan Kampus Unsoed

Hasil studi yang dilakukan oleh Ridwan dkk. [10] menunjukkan bahwa layanan VoIP layak untuk diterapkan di jaringan lokal atau kampus Unsoed. Purwarupa server VoIP/IP PBX memakai Asterisk telah berhasil dibangun oleh Pradipta dkk. [11] dan telah dilakukan pengujian QoS serta QoE dengan hasil yang menyatakan bahwa kualitas layanan VoIP di jaringan lokal Unsoed termasuk dalam kategori baik. Hal ini senada dengan hasil penelitian Tambunan dkk. [12] yang melakukan studi tentang unjuk kerja video over Internet Protocol dengan Asterisk dan dibandingkan dengan BigBlueButton, serta Nugraha dkk. [13] yang menyertakan pula pengujian dengan perangkat bergerak berbasis Android dan jaringan 
nirkabel/WiFi. Pengujian lima jenis codec/kodek pada sistem VoIP di jaringan lokal Unsoed juga telah dilakukan dan memberikan hasil yang baik jika dibandingkan dengan standar ITU-T [14].

Asterisk [15] merupakan perangkat lunak server komunikasi VoIP yang cukup terkenal dan banyak digunakan. Dengan perangkat lunak ini, masyarakat dapat membangun sebuah IP PBX dengan mudah dan memiliki fitur yang beragam seperti Interactive Voice Response (IVR), serta dukungan komunitas yang besar. FreeSWITCH [16] yang muncul belakangan tersedia sebagai mesin softswitch yang memiliki variasi perluasan fungsi. Perangkat lunak ini dikembangkan karena keinginan pengembang untuk mengisi kekosongan desain dan fitur pada Asterisk seperti arsitektur perangkat lunak, fleksibilitas, unjuk kerja, dan skalabilitas [17]-[20]. Kedua perangkat lunak server ini mendukung Session Initiation Protocol (SIP) [21] untuk pensinyalan dan Real-time Transport Protocol (RTP) [22] untuk transfer media pada komunikasi VoIP.

Penelitian-penelitian sebelumnya melakukan uji kelayakan jaringan lokal untuk implementasi VoIP [10] dan evaluasi unjuk kerja pada sistem VoIP berbasis Asterisk [11]-[14]. Penelitian yang lain melakukan perbandingan protokol SIP/RTP dan IAX [23], [24]. Terdapat pula penelitian tentang penggunaan FreeSWITCH untuk IP PBX/IVR [25], tanpa evaluasi QoS maupun QoE untuk sistem yang telah dibangun. Penelitian yang membandingkan server-server VoIP yaitu Asterisk, FreeSWITCH, dan Yate dilakukan oleh Tomičić dkk. [26]. Namun, eksperimen dan pengujian yang dilakukan pada penelitian tersebut hanya menggunakan satu perangkat keras server dan klien VoIP, serta fokus penelitian tersebut adalah kapasitas panggilan pada ketiga server melalui simulasi dari program penguji/pembangkit lalu lintas VoIP. Konsumsi sumber daya yang diukur saat pengujian adalah prosesor saja. Dari keseluruhan penelitian yang telah disebutkan, belum ada yang melakukan penelitian sistem VoIP dari sisi arsitektur jaringan dengan topologi bertingkat pada jaringan kampus, dan bagaimana pengaruh penempatan IP PBX pada hierarki topologi jaringan terhadap unjuk kerja VoIP. Sebagai perbandingan, dipakai Asterisk dan FreeSWITCH untuk melihat keterkaitan perangkat lunak server VoIP tersebut terhadap unjuk kerja IP PBX pada topologi bertingkat di jaringan kampus.

Dari hal-hal yang telah disebutkan sebelumnya, kontribusi makalah ini dapat dituliskan sebagai berikut.

1. Arsitektur jaringan eksperimen didesain sebagai miniatur/model topologi bertingkat di jaringan kampus yang diadaptasi dari arsitektur global jaringan kampus pada lokasi penelitian, termasuk penempatan dua IP PBX di hierarki yang berbeda pada topologi jaringan.
2. Ditinjau kembali dan menjelaskan salah satu parameter QoS yaitu end-to-end delay sesuai dengan arsitektur sistem dasar end-to-end dengan tambahan elemen VoIP yaitu IP PBX.

3. Dilakukan pengujian/evaluasi unjuk kerja VoIP (QoS dan QoE) pada dua IP PBX yang menggunakan perangkat lunak server VoIP Asterisk dan FreeSWITCH pada topologi bertingkat di jaringan eksperimen dengan skenario phone-to-phone. Jaringan ini terhubung ke jaringan kampus aktif. Selain itu, konsumsi sumber daya IP PBX yaitu prosesor dan memori untuk masing-masing server VoIP kami ukur pada saat pengujian dilakukan.

4. Dibandingkan unjuk kerja VoIP antara IP PBX Asterisk dan FreeSWITCH dari hasil pengujian, kemudian melihat pengaruh penempatan IP PBX pada hierarki topologi yang berbeda terhadap unjuk kerja VoIP.

\section{METODE PENELITIAN}

Penelitian ini kami melakukan dengan tahapan persiapan, perancangan, dan pembangunan sistem VoIP terlebih dahulu termasuk penempatan IP PBX di topologi jaringan eksperimen yang terhubung ke jaringan lokal aktif, kemudian dilakukan pengujian dan evaluasi dengan menggunakan parameterparameter QoS yaitu delay, jitter, dan packet loss, serta QoE dengan menggunakan MOS untuk mengukur kualitas suara secara subjektif oleh pemanggil dan penerima, ditambah dengan pengukuran persentase konsumsi prosesor dan memori saat komunikasi VoIP dilakukan.

\section{A. Perangkat Keras dan Perangkat Lunak}

Perangkat keras yang digunakan pada penelitian ini adalah dua buah perangkat keras komputer server, satu buah switch, dan dua buah telepon VoIP yang rincian spesifikasinya dapat dilihat pada Tabel 1 . Semuanya merupakan perangkat keras umum dan bisa didapatkan di pasaran (commodity hardware).

\begin{tabular}{ccc}
\multicolumn{3}{c}{ Tabel 1. Spesifikasi Perangkat Keras. } \\
\hline Jenis & Spesifikasi & Jumlah \\
\hline Server & Xeon E3-1220 3.10 GHz, & 1 buah \\
IBM & RAM DDR3 2GB, Harddisk 500GB & \\
Server & Xeon E3-1230 3.30 GHz, & 1 buah \\
Rainer & RAM DDR3 4GB, Harddisk 1TB & \\
Switch & HP ProCurve 1810G-24 (managed) & 1 buah \\
$\begin{array}{c}\text { Telepon } \\
\text { VoIP }\end{array}$ & YeaLink SIP-T20 & 2 buah \\
\hline
\end{tabular}

Untuk perangkat lunak yang kami pakai terdiri dari sistem operasi Linux dengan distribusi Ubuntu, aplikasi server VoIP Asterisk dan FreeSWITCH, Wireshark untuk menganalisis paket jaringan, ditambah dengan ping dan MTR untuk membantu dalam perhitungan end-to-end delay. Spesifikasi perangkat lunak ini dapat dilihat pada Tabel 2. 
Tabel 2. Spesifikasi Perangkat Lunak.

\begin{tabular}{ccc}
\hline Jenis & Perangkat Lunak & Versi \\
\hline Sistem Operasi & Ubuntu & 12.0432 bit \\
Aplikasi Server VoIP & Asterisk & 11 \\
& FreeSWITCH & 1.2 stable \\
Penganalisis Jaringan & Wireshark & 1.8 .2 \\
\hline
\end{tabular}

Untuk melakukan pemantauan dan pengambilan data, kami memakai satu buah laptop yang sudah terpasang aplikasi SSH dan Wireshark.

\section{B. Protokol VoIP dan Kodek}

Protokol yang kami pakai pada sistem VoIP ini adalah SIP untuk fungsi pensinyalan (membangun, memodifikasi, dan menutup sesi komunikasi), serta RTP untuk protokol transfer media. Kedua protokol ini telah diimplementasikan ke dalam perangkat lunak Asterisk dan FreeSWITCH sehingga kami hanya perlu melakukan konfigurasi sesuai dengan rancangan riset.

Untuk kodek yang kami pakai dalam penelitian ini adalah G.711 yang menggunakan Pulse Code Modulation (PCM) dan merupakan standar komunikasi suara pada jaringan telepon yang mempunyai kualitas tinggi. Kodek ini membangkitkan sampel 8 bit setiap $0,125 \mathrm{~ms}$ sehingga memiliki laju bit 64 kbps [2], [3], [5], [6], dan didukung oleh banyak perangkat VoIP termasuk telepon YeaLink SIP-T20 yang kami pakai. Kodek ini sering menghasilkan nilai MOS di atas 4 [1], [3], [5], [6], [27].

\section{Topologi Jaringan dan Penempatan IP PBX}

Jika digambarkan dalam bentuk topologi bertingkat atau hierarkis, jaringan kampus Unsoed secara global dapat diilustrasikan seperti Gambar 3. Masing-masing tingkat direpresentasikan oleh perangkat switch yang memiliki kemampuan dan peran yang berbeda sesuai dengan hierarkinya di dalam jaringan.

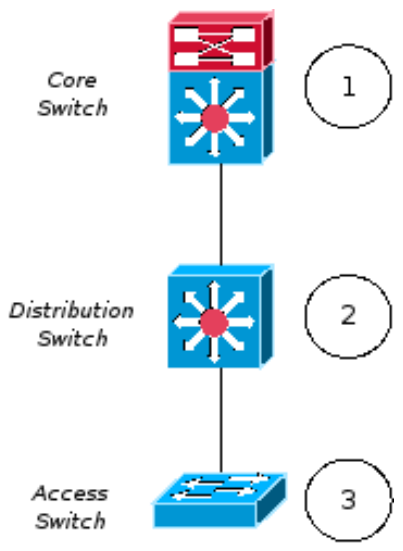

Gambar 3. Hierarki Perangkat di Jaringan Kampus Unsoed.

Dengan berdasar desain topologi bertingkat dengan hierarki perangkat ini, kami membuat sebuah jaringan eksperimen dengan tujuan untuk merepresentasikan topologi jaringan kampus Unsoed dengan lingkup yang kecil sebagai miniatur/model/purwarupa di lokasi penelitian.

Gambar 4 menunjukkan topologi jaringan eksperimen yang terhubung ke jaringan kampus Unsoed dengan representasi nomor yang berkorelasi terhadap hierarki perangkat pada Gambar 3. IP PBX pertama yang menggunakan server IBM diletakkan di ruang server, Gedung A, terhubung ke switch nomor 1. IP PBX kedua yang menggunakan komputer server Rainer ditempatkan di Laboratorium Jejaring dan Komputasi (LJK), Gedung B dan terhubung ke switch nomor 3 .

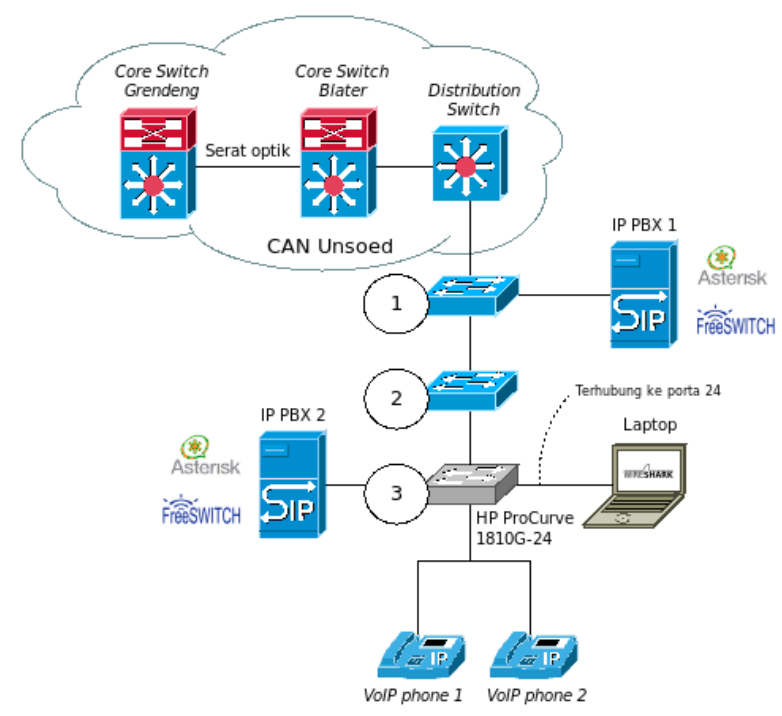

Gambar 4. Topologi Jaringan Eksperimen Dan Penempatan IP PBX, Serta Perangkat Switch Yang Mengacu Pada Hierarki Perangkat Di Jaringan Kampus Unsoed.

\section{Kualitas Layanan (QoS)}

QoS pada VoIP ditentukan oleh tiga parameter unjuk kerja jaringan yaitu packet delay, jitter, dan packet loss. Latensi/waktu tunda paket atau packet delay selanjutnya akan disebut dengan delay saja.

Delay adalah waktu yang diperlukan oleh sebuah paket yang dikirimkan dari sumber untuk mencapai ke tujuan. Parameter delay yang digunakan dalam QoS adalah delay dari ujung pemanggil ke ujung penerima atau mouth-to-ear delay atau one-way delay atau endto-end delay, bukan round-trip time (RTT). Rekomendasi ukuran end-to-end delay untuk aplikasi interaktif, percakapan, dan konferensi video termasuk VoIP adalah kurang dari 150 ms [5]-[8] dengan cakupan jarak sampai dengan 5000 kilometer, dan 300 ms untuk jarak lebih dari 27.500 kilometer [7]. Nilai $400 \mathrm{~ms}$ dianggap sebagai nilai maksimum agar kualitas komunikasi dapat diterima [7], [8] untuk jaringan Internet/best effort [6], [28].

Untuk mendapatkan end-to-end delay dibutuhkan penjumlahan delay pada ujung-ujung perangkat komunikasi dan delay jaringan. Delay jaringan dapat diperoleh dari penjumlahan delay transmisi, propagasi, antrian, dan pemrosesan [4]. Kami memperoleh delay 
jaringan dari pengujian ping (RTT) antara server/IP PBX dengan klien/telepon VoIP dari sisi pengirim, dan server/IP PBX dengan klien/telepon VoIP dari sisi penerima dengan jumlah 100 sampel. Hasil rata-rata penjumlahannya kemudian dibagi dua agar didapatkan nilai delay satu arah untuk transmisi. Kami dapat melakukan teknik ini karena jaringan yang dipakai adalah LAN [3] dan kami bisa memastikan bahwa rute yang ditempuh oleh paket adalah simetris. Teknik ini secara otomatis menyertakan delay propagasi, walaupun sebenarnya delay propagasi dapat diabaikan untuk jarak pendek seperti jaringan lokal/LAN [5], atau kurang dari $1000 \mathrm{~km}$ [29].

Delay antrian sifatnya beragam untuk tiap paket. Jika intensitas lalu lintas data mendekati nol atau paket di jaringan jarang menemui antrian, delay antrian juga mendekati nol [4], karena itu delay ini tidak kami sertakan dalam perhitungan. Delay pemrosesan dapat diabaikan karena umumnya berukuran sangat kecil [4], namun dalam penelitian ini kami menambahkannya untuk delay saat paket ditangkap oleh Wireshark di switch HP ProCurve 1810G-24. Berdasarkan hal-hal yang sudah dikemukakan, maka delay jaringan (dela $\left.y_{\text {jaringan }}\right)$ didapatkan dengan penjumlahan delay transmisi (delay transmisi $_{\text {in }}$ dan pemrosesan (delay pemrosesan $_{\text {) }}$ seperti terlihat pada rumus (1).

dela $_{\text {jaringan }}=$ delay $_{\text {transmisi }}+$ delay $_{\text {pemrosesan }}$

Delay kodek adalah waktu yang diperlukan enkoder dan dekoder (kodek) untuk menyandikan sampel percakapan ke dalam aliran bit/bitstream dan mengawasandikan kembali ke sampel percakapan [2]. Beberapa kodek membutuhkan waktu look-ahead saat melakukan penyandian, namun hal ini tidak ada atau bernilai 0 untuk kodek G.711. Minimum total delay

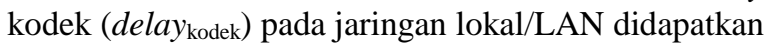
dengan menjumlahkan dua kali ukuran frame percakapan dan waktu look-ahead, seperti terlihat pada rumus (2) [2], [7].

delay $_{\mathrm{kodek}}=2 \mathrm{x}$ ukuran frame percakapan + lookahead

Ukuran frame percakapan, waktu look-ahead, delay kodek dan paketisasi untuk kodek G.711 dapat dilihat pada Tabel 3 [2], [3], [5], [6], [24], [30].

Tabel 3. Ukuran Frame, Look-Ahead, Delay Kodek Dan Paketisasi.

\begin{tabular}{ccccc}
\hline Kodek & $\begin{array}{c}\text { Speech } \\
\text { Frame } \\
(\mathbf{m s})\end{array}$ & $\begin{array}{c}\text { Look- } \\
\text { ahead } \\
(\mathbf{m s})\end{array}$ & $\begin{array}{c}\text { Delay } \\
\text { Kodek } \\
(\mathbf{m s})\end{array}$ & $\begin{array}{c}\text { Delay } \\
\text { Paketisasi } \\
(\mathbf{m s})\end{array}$ \\
\hline G.711 & 0,125 & 0 & 0,25 & 20 \\
\hline
\end{tabular}

Delay end-to-end (delay ere ) bisa didapatkan dengan melakukan penjumlahan delay $y_{\text {jaringan }}(1)$, delay $y_{\text {kodek }}(2)$,

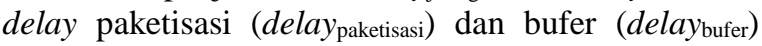
[2], lihat rumus (3).

delay $_{e 2 e}=$ delay $_{\mathrm{kodek}}+$ dela $_{\mathrm{paketisasi}}+$ delay $_{\mathrm{jaringan}}+$ delaybufer
Delay paketisasi adalah waktu yang diperlukan untuk membangun sebuah paket data pada pengirim dengan memformat bit yang akan dikirim menjadi paket termasuk memasang header dan mengisi bagian payload paket [5], [29]. Delay paketisasi untuk kodek G.711 adalah $20 \mathrm{~ms}$, jika sebuah paket terdiri dari satu frame percakapan [2], [5], [29], lihat Tabel 3. Pada penerima terdapat delay depaketisasi dan delay bufer atau jitter buffer [2], [5]. Delay depaketisasi memiliki nilai yang berkolerasi dengan delay paketisasi [31], [32]. Nilai delay jitter buffer yang umum dipakai adalah $60 \mathrm{~ms}$ [31], namun dalam penelitian ini kami mengabaikan nilainya karena sistem VoIP berada di jaringan lokal/LAN berkecepatan tinggi dengan kemungkinan jitter yang sangat kecil.

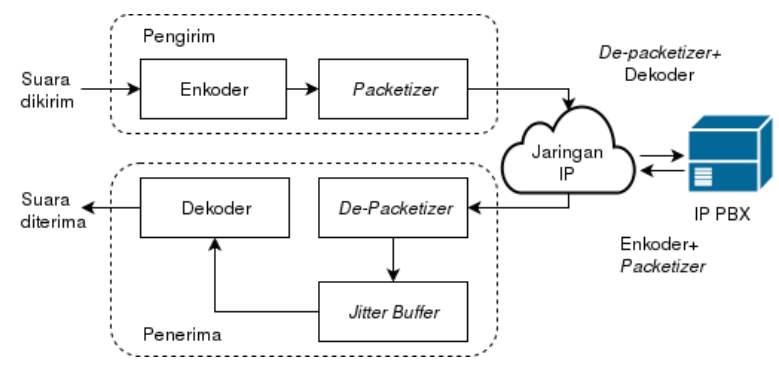

Gambar 5. Elemen End-To-End Sistem VoIP dengan IP PBX.

Rumus (3) digunakan jika antara pengirim dan penerima terhubung seperti Gambar 1. Berbeda dengan topologi penelitian ini yang memiliki IP PBX di antara pengirim dan penerima, sehingga ilustrasinya dapat dilihat seperti Gambar 5. Pada gambar tersebut terdapat dua panggilan, yang pertama dari pengirim ke IP PBX dan yang kedua dari IP PBX ke penerima. Jika masing-masing panggilan memiliki nilai delay end-toend yaitu delay kodek $_{\text {ditambah delay }}$ paketisasi untuk masing-masing panggilan pertama (delay $y_{\mathrm{e} 2 \mathrm{e}-\mathrm{sender} 2 \mathrm{pbx}}$ ) dan panggilan kedua (delay $y_{\mathrm{e} 2 \mathrm{e}-\mathrm{pb} \times 2 \text { receiver}}$ ), total delay end-to-end (delay e2e-total ) dapat dituliskan seperti rumus (4).

delay $_{\mathrm{e} 2 \mathrm{e}-\mathrm{total}}=$ delay $_{\mathrm{e} 2 \mathrm{e}-\mathrm{sender} 2 \mathrm{pbx}}+$ delay $_{\mathrm{e} 2 \mathrm{e}-\mathrm{pb} 2 \text { receiver }}+$ delay jaringan

Jitter atau packet delay variation merupakan variasi delay antar paket yang umumnya disebabkan oleh kemacetan dan antrian di dalam jaringan [2], [6]. Delay pemrosesan dan antrian paket oleh perangkat jaringan berpengaruh terhadap parameter ini. Nilai jitter ideal paling tidak sebesar $30 \mathrm{~ms}$ [6]. ETSI TIPHON menggunakan nilai $75 \mathrm{~ms}$ untuk peak jitter, dan nilai ini masuk ke dalam kategori "Bagus" [29].

Kehilangan paket atau packet loss adalah parameter yang menunjukkan jumlah paket yang tidak mencapai tujuan (hilang). Karakteristik packet loss dalam kondisi baik atau dapat diterima adalah jika kurang dari 2\% [6] atau 3\% [8], [29]. 


\section{E. Kualitas Pengalaman ( $Q o E)$}

QoE adalah parameter kualitas yang ditentukan oleh persepsi pengguna secara subjektif terhadap layanan yang tersedia, dalam hal ini adalah VoIP [2]. Kami menggunakan parameter MOS [9] untuk mengukur QoE dari sisi pemanggil dan penerima. MOS memiliki nilai rentang dari 1 sampai dengan 5 yang dapat dilihat pada Tabel 4 [9] [14].

Tabel 4. Nilai MOS

\begin{tabular}{ccc}
\hline Nilai & Kualitas & Keterangan \\
\hline 5 & Excellent & Tidak ada derau \\
4 & Good & Ada derau dan tidak mengganggu \\
3 & Fair & Ada derau dan sedikit mengganggu \\
2 & Poor & Ada derau dan mengganggu \\
1 & Bad & Ada derau dan sangat mengganggu \\
\hline
\end{tabular}

Kami menanyakan pada penguji dari sisi pemanggil dan penerima tentang kualitas komunikasi VoIP pada setiap pengujian. Setiap penguji diminta untuk menentukan kualitas komunikasi VoIP berdasarkan nilai MOS, seperti yang terdapat pada Tabel 4. Setelah semua nilai MOS untuk setiap pasang penguji (pengirim dan penerima) telah dikumpulkan, dilakukan perhitungan nilai reratanya.

\section{F. Konsumsi Prosesor dan Memori}

Kami mengukur persentase konsumsi prosesor dan memori untuk mengetahui seberapa besar kebutuhan IP PBX saat komunikasi VoIP dilakukan. Berkaitan dengan tujuan perbandingan, kami juga ingin mengetahui perbedaan konsumsi sumber daya antara perangkat lunak Asterisk dan FreeSWITCH.

Kami menggunakan perintah top yang dapat menampilkan jumlah pemakaian sumber daya sebuah program di dalam sebuah sistem.

\section{G. Rancangan Penelitian}

Penelitian dilakukan dengan perancangan dan pembangunan terlebih dahulu IP PBX dengan dua perangkat keras komputer server yang telah tersedia. Masing-masing server dipasang dengan perangkat lunak Asterisk dan FreeSWITCH. Kami melakukan konfigurasi untuk keduanya sesuai dengan jaringan, alamat IP, identitas klien VoIP, protokol transpor, pensinyalan, sistem penomoran, dial plan, dan pemilihan kodek yang sudah ditentukan. Penomoran pada sistem VoIP dapat dilihat pada Tabel 5. Angka pertama menandakan IP PBX yang dipakai, dan angka keeempat menandakan perangkat lunak server VoIP, "1" untuk Asterisk dan "2" untuk FreeSWITCH.

Konfigurasi telepon VoIP Yealink T-20 dilakukan dengan menggunakan panel administrasi yang dapat diakses melalui peramban/browser web. Hal-hal yang perlu dikonfigurasi di antaranya adalah nama pengguna, kata sandi, dan server SIP. Konfigurasi ini dilakukan dengan mengacu pada sistem penomoran yang ada pada Tabel 5 sesuai dengan IP PBX dan perangkat lunak server VoIP yang dituju.

Sebagai catatan, telepon VoIP yang kami gunakan menyediakan dua akun SIP sehingga memudahkan kami melakukan pemilihan perangkat lunak server yang dituju apakah Asterisk atau FreeSWITCH pada IP PBX yang sedang diuji. Kami mengeset akun satu untuk Asterisk dan akun dua untuk FreeSWITCH.

Tabel 5. Penomoran Pada Sistem VoIP.

\begin{tabular}{cccc}
\hline \multicolumn{2}{c|}{ IP PBX 1 } & \multicolumn{2}{c}{ IP PBX 2 } \\
\hline Asterisk & FreeSWITCH & Asterisk & FreeSWITCH \\
\hline 100101 & 100201 & 200101 & 200201 \\
100102 & 100202 & 200102 & 200202 \\
\hline
\end{tabular}

Setelah pemasangan dan konfigurasi pada tahap pembangunan selesai, kedua IP PBX diletakkan di jaringan sesuai dengan topologi yang sudah dijelaskan pada subbagian $\mathrm{C}$.

Kami melakukan pengujian dengan skenario phone-to-phone. Telepon VoIP satu dipakai untuk melakukan panggilan ke telepon VoIP yang lain dan pengujian dilakukan sebanyak 5 kali dengan masingmasing berisi percakapan selama 30 detik. Saat melakukan pengujian Asterisk maupun FreeSWITCH pada masing-masing IP PBX, kami mematikan salah satu perangkat lunak tersebut sehingga yang berjalan hanya Asterisk atau FreeSWITCH saja.

Semua parameter QoS diukur menggunakan Wireshark, hanyasanya untuk parameter delay memerlukan perhitungan manual/lebih lanjut karena yang kami inginkan adalah one-way delay atau end-toend delay. Parameter QoE berupa nilai MOS didapatkan dengan menanyakan persepsi pengguna VoIP baik pemanggil maupun penerima terhadap layanan yang dipakai pada saat pengujian. Nilai konsumsi prosesor dan memori didapatkan dengan memantau server VoIP yang sedang diuji dengan perintah top. Hal ini juga sudah dibahas pada subbagian D, E, dan F.

Untuk pengukuran, kami menggunakan sebuah laptop yang terhubung pada porta di switch HP ProCurve 1810G-24 yang sudah diset fungsi port mirroring yaitu pada porta nomor 24. Wireshark yang terpasang pada laptop dijalankan dengan mode promiscuous supaya dapat menangkap semua paket pada antarmuka jaringan laptop.

Setelah hasil pengujian diperoleh, kami melakukan analisis/perbandingan antara IP PBX Asterisk dan FreeSWITCH dengan melihat parameter QoS dan QoE, serta persentase konsumsi prosesor dan memori, kemudian melihat kaitannya dengan penempatan IP PBX pada hierarki topologi yang berbeda di jaringan eksperimen. 


\section{HASIL DAN PEMBAHASAN}

\section{A. Langkah-Langkah Pengujian}

Langkah pertama pengujian adalah dengan menjalankan Wireshark sebagai administrator (root) dan selanjutnya kami memantau lalu lintas data yang melewati access switch HP ProCurve 1810G-24 melalui porta 24 yang sebelumnya kami set ke port mirroring. Antarmuka yang dipakai adalah Ethernet pada laptop (eth0).

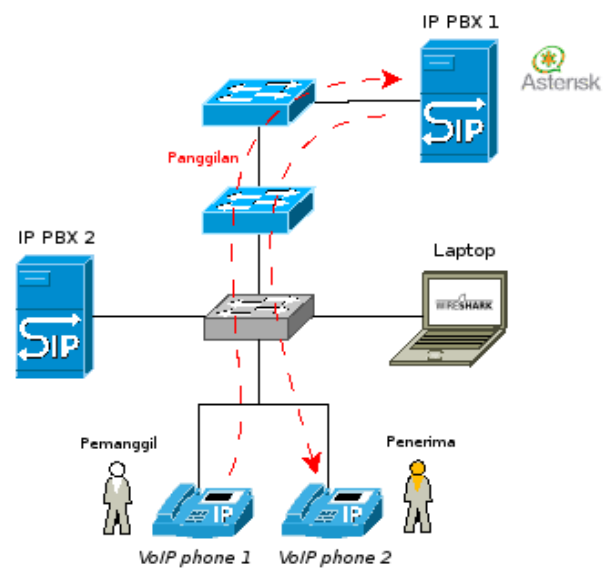

Gambar 6. Pengujian Asterisk pada IP PBX 1.

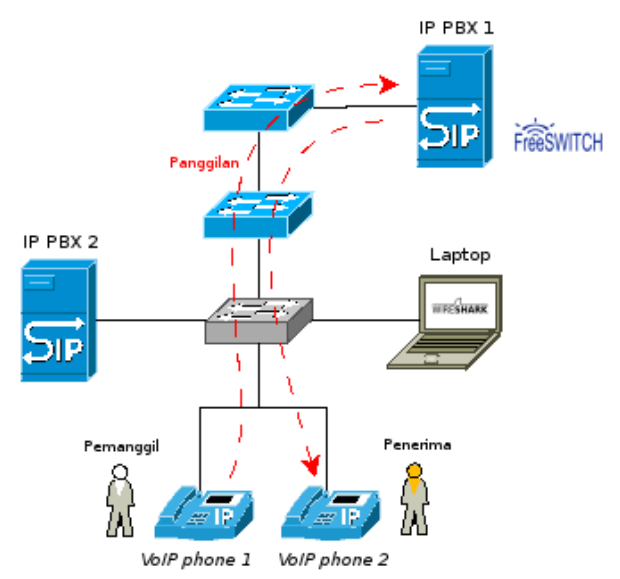

Gambar 7. Pengujian FreeSWITCH pada IP PBX 1.

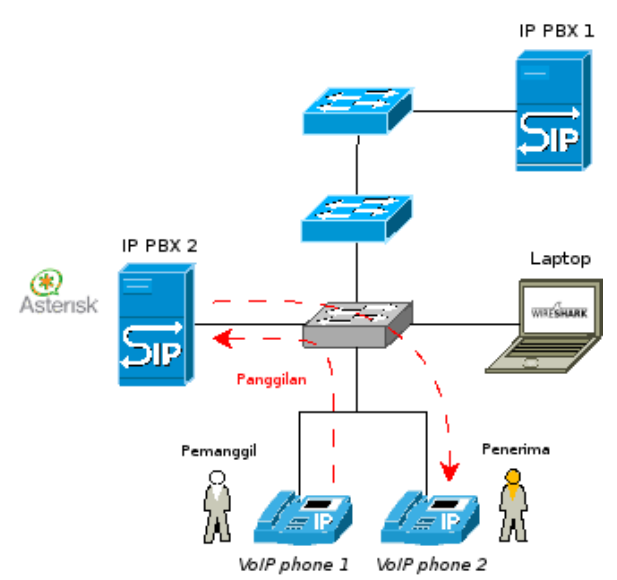

Gambar 8. Pengujian Asterisk pada IP PBX 2.
Langkah kedua adalah dengan melakukan panggilan dari pesawat telepon VoIP satu ke yang lain sesuai dengan skenario pengujian yaitu Asterisk pada IP PBX 1, FreeSWITCH pada IP PBX 1, Asterisk pada IP PBX 2, dan FreeSWITCH pada IP PBX 2. Ilustrasi masing-masing pengujian dapat dilihat pada Gambar 6, 7, 8, dan 9.

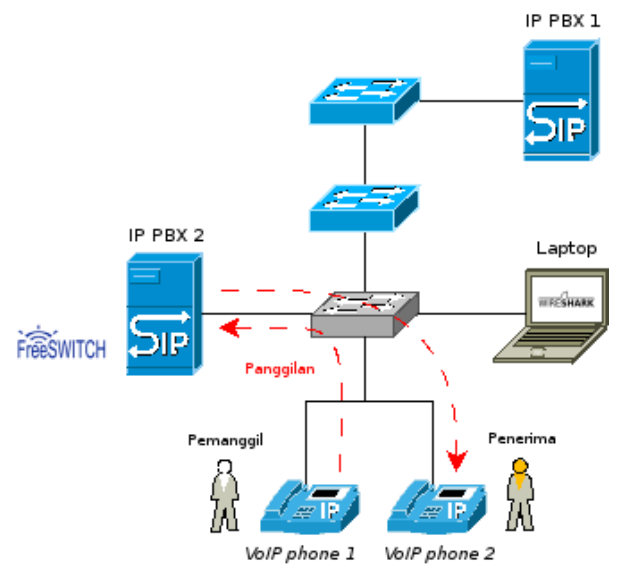

Gambar 9. Pengujian FreeSWITCH pada IP PBX 2.

Kami menggunakan dua tombol pada telepon VoIP untuk berpindah dari satu akun ke akun yang lain pada IP PBX yang sedang diuji. Saat pengujian satu perangkat lunak server VoIP, kami mematikan perangkat lunak server yang lain. Contoh, jika kami akan menguji Asterisk pada IP PBX 1, maka kami akan mematikan FreeSWITCH pada IP PBX 1, dan menggunakan tombol satu di telepon VoIP untuk mengaktifkan akun di Asterisk.

\section{B. Hasil Pengujian}

Setelah pengujian dilakukan, kami melakukan pengumpulan dan analisis data hasil pengukuran. Untuk jitter dan packet loss bisa kami dapatkan langsung dari Wireshark, sedang nilai delay memerlukan kalkulasi lebih lanjut untuk mendapat total delay end-to-end. Kami menggunakan nilai rerata dari seluruh data untuk setiap parameter QoS.

Delay yang perlu dicari terlebih dahulu adalah delay jaringan yang diperoleh dari penjumlahan delay transmisi dan pemrosesan, lihat rumus (1). Delay transmisi didapatkan dengan cara mengirimkan paket ICMP Echo Request melalui program ping dari IP PBX ke telepon VoIP satu dan dari IP PBX ke telepon VoIP dua. Sesuai dengan yang dijelaskan pada bagian II subbagian D, jumlah ping yang kami lakukan sebanyak 100 kali, kemudian kami mencari nilai reratanya dan didapatkan nilai $0,5 \mathrm{~ms}$.

Data delay yang kami dapatkan dari Wireshark berupa nilai delay pemrosesan di access switch HP ProCurve 1810G-24, tempat lalu lintas VoIP ditangkap [33]. Delay pemrosesan tersebut diperoleh dengan mengetahui selisih waktu/timestamp dua paket RTP dari sumber ke tujuan. Untuk mengetahuinya, kami dapat melihat dua paket yang memiliki nilai 
timestamp sama di jendela "Packet List" pada Wireshark. Namun, kami perlu terlebih dahulu melakukan filter terhadap keluaran Wireshark dengan menyertakan hanya paket RTP saja. Kami mengambil 10 sampel pasangan paket dengan timestamp yang sama kemudian kami mencari selisih waktu dan mencari nilai reratanya.

Dengan nilai rerata delay transmisi (delay transmisi $_{\text {) }}$

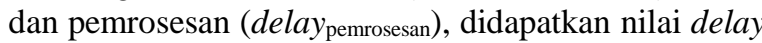
jaringan (delay $\left.y_{\text {jaringan }}\right)$, lihat rumus (1). Untuk

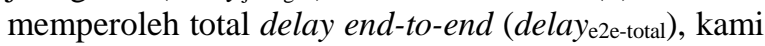
perlu mendapatkan delay end-to-end panggilan pertama (delay $\left.y_{\mathrm{e} 2 \mathrm{e}-\mathrm{sender} 2 \mathrm{pbx}}\right)$ dan panggilan kedua

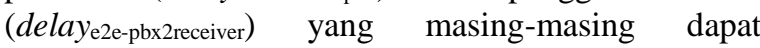
diperoleh dengan menjumlahkan delaykodek dan

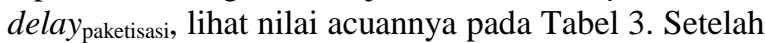
delay end-to-end dua panggilan tersebut sudah didapatkan, kami menjumlahkannya dengan delay jaringan sehingga didapatkan total delay end-to-end, sesuai rumus (4).

Untuk jitter dan packet loss diperoleh dengan cara menggunakan fungsi analisis VoIP untuk paket RTP. Kami menggunakan menu Telephony-RTP-Show All Streams. Setelah mengklik menu tersebut, kami memilih semua aliran yang sesuai untuk panggilan dari telepon VoIP satu ke telepon VoIP yang lain melalui IP PBX pada jendela "Wireshark: RTP Streams". Setiap aliran pada jendela tersebut masingmasing dipilih kemudian disimpan hasilnya ke format berkas CSV. Nilai jitter didapatkan dengan mencari nilai rerata data jitter untuk seluruh aliran komunikasi. Kami tidak perlu mencari rerata untuk parameter packet loss karena nilai yang didapatkan sama yaitu 0 .

Data hasil pengukuran semua parameter QoS dan QoE untuk nilai rata-rata dari 5 kali pengujian dapat dilihat pada Tabel 6 , termasuk konsumsi prosesor dan memori.

Tabel 6. Hasil Pengujian QoS, QoE, dan Konsumsi Sumber Daya

\begin{tabular}{ccccc}
\hline \multirow{2}{*}{ Parameter } & \multicolumn{2}{c}{ IP PBX 1 } & \multicolumn{2}{c}{ IP PBX 2 } \\
\cline { 2 - 5 } & Asterisk & FS & Asterisk & FS \\
\hline Delay (ms) & 41,490 & 41,012 & 41,020 & 41,016 \\
Jitter (ms) & 0,089 & 0,060 & 0,101 & 0,066 \\
Pack. Loss (\%) & 0 & 0 & 0 & 0 \\
MOS & 4,9 & 5 & 4,8 & 5 \\
Prosesor (\%) & 0,5 & 1 & 0,6 & 1,08 \\
Memori (\%) & 1,2 & 1 & 0,7 & 0,5 \\
\hline
\end{tabular}

Tabel 6 memperlihatkan bahwa IP PBX FreeSWITCH lebih unggul pada delay, jitter, MOS, dan konsumsi memori, sedang IP PBX Asterisk lebih unggul pada konsumsi prosesor, walaupun nilai masing-masingnya terpaut sedikit. Parameter packet loss dari kedua IP PBX untuk dua server VoIP bernilai sama yaitu $0 \%$, hal ini dapat dipahami mengingat jaringan yang dipakai adalah LAN dan masih dalam rentang jarak yang pendek.

Disebutkan pada [2] dan [5] bahwa ketika delay di ujung-ujung sistem baik berupa perangkat lunak aplikasi maupun perangkat fisik seperti telepon VoIP bernilai tetap, maka yang banyak berpengaruh terhadap nilai total delay end-to-end adalah delay jaringan. Kami memisahkan nilai delay jaringan sehingga hasilnya dapat dilihat pada Tabel 7.

Tabel 7. Hasil Pengujian Qos Untuk Delay Jaringan Saja

\begin{tabular}{ccccc}
\hline \multirow{2}{*}{ Parameter } & \multicolumn{2}{c}{ IP PBX 1 } & \multicolumn{2}{c}{ IP PBX 2 } \\
\cline { 2 - 5 } & Asterisk & FS & Asterisk & \multirow{2}{*}{ FS } \\
\hline Delay $(\mathrm{ms})$ & 0,990 & 0,512 & 0,520 & 0,516 \\
\hline
\end{tabular}

Tabel 7 menunjukkan bahwa delay jaringan Asterisk pada IP PBX 1 ketika dibandingkan dengan Asterisk pada IP PBX 2 bernilai cukup besar. Di sisi lain, hal ini tidak terjadi pada FreeSWITCH pada kedua IP PBX.

Kami melakukan pengujian ulang untuk memastikan bahwa data pada Tabel 7 adalah valid. Setelah dilakukan pengujian ulang didapatkan hasil seperti pada Tabel 8 .

Tabel 8. Hasil Pengujian Ulang Qos Untuk Delay Jaringan Saja

\begin{tabular}{ccccc}
\hline \multirow{2}{*}{ Parameter } & \multicolumn{2}{c}{ IP PBX 1 } & \multicolumn{2}{c}{ IP PBX 2 } \\
\cline { 2 - 5 } & Asterisk & FS & Asterisk & FS \\
\hline Delay $(\mathrm{ms})$ & 0,949 & 0,516 & 0,704 & 0,511 \\
\hline
\end{tabular}

Kami lebih lanjut melakukan pengujian dengan memastikan sistem pada IP PBX 1 tidak menjalankan layanan-layanan lain yang mungkin dapat mengganggu lingkungan pengujian, dan hasil yang diperoleh adalah nilai delay sebesar 0,945 untuk Asterisk. Dari hasil dua pengujian ulang tersebut dapat dipastikan bahwa delay jaringan untuk Asterisk pada IP PBX 1 berkisar pada nilai tersebut.

Jika dibandingkan, delay jaringan pada FreeSWITCH terlihat lebih stabil nilainya untuk IP PBX 1 yang diletakkan di core switch maupun IP PBX 2 yang berada di access switch, meskipun pada core switch terdapat lalu lintas aktif dan cukup tinggi. Kami menduga FreeSWITCH memiliki keunggulan dalam arsitektur dan mekanisme untuk menangani lalu lintas percakapan dan data sehingga lokasi penempatan relatif tidak berpengaruh pada delay jaringan yang diperoleh. Jika dibandingkan, Asterisk pada IP PBX 2 memiliki nilai yang kurang stabil pada parameter delay jaringan, lihat Tabel 7 dan Tabel 8.

Nilai delay jaringan yang diperoleh dari hasil pengujian memang relatif kecil, tetapi dengan skala yang lebih besar dalam hal ukuran jaringan, jarak, medium yang dipakai dan lokasi antar perangkat, serta lalu lintas jaringan, maka perbedaan nilai ini akan terlihat jelas. Salah satu bukti yang mengkonfirmasi hal ini dapat dilihat pada hasil penelitian tentang unjuk 
kerja VoIP pada jaringan WiMAX dengan 7 lokasi pengujian dan rentang jarak kurang lebih 1-7 km [34].

\section{PENUTUP}

\section{A. Kesimpulan}

Kami telah mendesain arsitektur jaringan eksperimen yang diadaptasi dari topologi bertingkat di jaringan kampus di lokasi penelitian. Konsep eksperimen ini diharapkan dapat menjadi dasar untuk mendesain arsitektur IP PBX secara terpusat dan tersebar di jaringan kampus. Kami membangun dua IP PBX dengan menggunakan perangkat lunak server VoIP Asterisk dan FreeSWITCH pada dua perangkat keras/komputer server yang berbeda, kemudian menempatkannya di hierarki topologi yang berbeda pada jaringan eksperimen. Hal ini dilakukan untuk mengetahui perbandingan IP PBX Asterisk dan FreeSWITCH serta pengaruh penempatan IP PBX terhadap unjuk kerja VoIP pada topologi bertingkat di jaringan eksperimen.

Kami menilik kembali konsep end-to-end delay dengan mengacu ke elemen end-to-end sistem VoIP (Ggambar 1) dan menambahkan komponen IP PBX (Ggambar 5), sehingga metode pengukuran end-toend delay dapat ditentukan sesuai dengan diagram/alur yang dipakai. Penjelasan ini dapat ditemukan pada bagian II subbagian D.

Pengujian unjuk kerja VoIP kami lakukan pada dua IP PBX dengan kombinasi Asterisk dan FreeSWITCH serta skenario phone-to-phone di jaringan eksperimen yang terhubung ke jaringan kampus aktif. Dari semua pengujian yang kami lakukan didapatkan hasil yang tergolong ke dalam kategori baik pada kedua IP PBX dari sisi QoS maupun QoE sesuai standar ITU-T dan ETSI TIPHON. Berdasarkan hasil penelitian, IP PBX FreeSWITCH sedikit lebih unggul daripada IP PBX Asterisk untuk QoS pada parameter delay dan jitter, QoE dengan MOS, dan konsumsi memori yang bernilai 41,012, 0,060, 5, $1 \%$ untuk IP PBX 1 dan 41,016, 0,066, 5, 0,5\% untuk IP PBX 2. Di sisi lain, IP PBX Asterisk unggul dalam hal konsumsi prosesor yang lebih kecil dengan 0,5\% untuk IP PBX 1 dan $0,6 \%$ untuk IP PBX 2.

Penempatan IP PBX pada hierarki di topologi jaringan eksperimen yang terhubung ke jaringan kampus aktif berpengaruh terhadap unjuk kerja VoIP khususnya untuk parameter delay pada IP PBX Asterisk. IP PBX FreeSWITCH terlihat stabil dari hasil pengujian yang sudah dilakukan dengan rentang perbedaan yang kecil. Kami menduga hal ini terjadi karena arsitektur perangkat lunak dan mekanisme dalam menangani lalu lintas percakapan dan data di jaringan. Spesifikasi perangkat keras komputer belum dapat disimpulkan berpengaruh terhadap unjuk kerja VoIP karena skala pengujian panggilan yang masih terbatas.

\section{B. Saran}

Kami menyarankan untuk dilakukan penelitian dengan skala jaringan yang lebih luas/global pada topologi bertingkat di jaringan kampus. Hal ini diperlukan untuk mengetahui keterkaitan penelitian yang dilakukan pada skala terbatas dengan skala yang lebih luas/global/sebenarnya, termasuk delay jaringan yang dibahas pada akhir bagian III.

Selain itu, penelitian yang berkaitan dengan kemampuan dalam menangani panggilan pada IP PBX dapat dilakukan untuk melihat kapasitas panggilan konkuren khususnya pada IP PBX Asterisk dan FreeSWITCH di jaringan kampus dengan topologi bertingkat baik dengan skala terbatas maupun luas. Konsumsi prosesor serta memori saat pengujian skalabilitas ini perlu dilakukan pula untuk mengetahui sumber daya yang dibutuhkan dan kaitannya dengan jenis perangkat lunak server serta kebutuhan spesifikasi perangkat keras untuk IP PBX. Hasil penelitian ini diharapkan dapat melengkapi dan mengkonfirmasi penelitian-penelitian yang telah ada, misal yang dilakukan oleh Tomičić dkk. [26].

Penjelasan salah satu parameter QoS yaitu end-toend delay yang dipaparkan pada penelitian ini terutama pada penyesuaian elemen/alur end-to-end sistem VoIP ke kondisi sistem yang nyata dapat dijadikan pertimbangan ketika melakukan penelitian unjuk kerja IP PBX.

\section{UCAPAN TERIMA KASIH}

Penelitian ini merupakan salah satu bagian dari penelitian multitahun yang didanai oleh skema Riset Unggulan Perguruan Tinggi Unsoed dengan sumber dana desentralisasi Dikti melalui LPPM Unsoed.

Kami menyampaikan terima kasih kepada Lembaga Pengembangan Teknologi dan Sistem Informasi (LPTSI), Fakultas Teknik, dan Jurusan Teknik Elektro Unsoed yang telah memberikan dukungan pada penelitian ini.

Terima kasih pula kami sampaikan untuk dua reviewer anonim yang telah memberikan komentar dan masukan pada makalah ini khususnya reviewer dua.

\section{DAFTAR PUSTAKA}

[1] R. Swale dan D. Collins, Carrier-Grade VoIP, 3rd ed. McGraw-Hill Education, 2014.

[2] L. Sun, I. Mkwawa, E. Jammeh, dan E. Ifeachor, Guide to Voice and Video over IP: For Fixed and Mobile Networks, Comput. Commun. and Networks. Springer, 2013.

[3] H.P. Singh, S. Singh, J. Singh, dan S.A. Khan, "VoIP: State of art for global connectivity-A critical review", J. of Network and Comput. Appl., vol. 37, 2014.

[4] J.F. Kurose dan K.W. Ross, Computer Networking: A Top-Down Approach, 6th ed. Pearson, 2013.

[5] K. Salah, "On the deployment of VoIP in Ethernet networks: methodology and case study", Comput. Commun., vol. 29, 2006. 
[6] S. Karapantazis dan F. Pavlidou, "VoIP: A comprehensive survey on a promising technology", Comput. Network, vol. 53, no. 12, 2009.

[7] ITU Telecommunication Standardization Sector (ITUT), "One-way transmission time", ITU-T Recommendation G.114, 2003.

[8] ITU Telecommunication Standardization Sector (ITUT), "End-user multimedia QoS categories", ITU-T Recommendation G.1010, 2001.

[9] ITU Telecommunication Standardization Sector (ITUT), "Methods for subjective determination of transmission quality", ITU-T Recommendation P.800, 1996.

[10] M. Ridwan, A.W.W. Nugraha, dan H. Susilawati, "Uji kelayakan jaringan lokal Universitas Jenderal Soedirman untuk implementasi VoIP", Dinamika Rekayasa, vol. 7, no. 1, Februari 2011.

[11] A. Pradipta, A.W.W. Nugraha, dan I. Setiawan, "Unjuk kerja Voice over Internet Protocol pada jaringan lokal Universitas Jenderal Soedirman", Dinamika Rekayasa, vol. 8, no. 2, Agustus 2012.

[12] H.B. Tambunan, I. Setiawan, dan A.W.W. Nugraha, "Unjuk kerja video over Internet Protocol menggunakan Asterisk dan BigBlueButton pada jaringan lokal Universitas Jenderal Soedirman", Seminar Nasional Pengembangan Sumber Daya Pedesaan dan Kearifan Lokal Berkelanjutan III, 2013.

[13] A.W.W. Nugraha, I. Setiawan, dan I. Rosyadi, "Penerapan Voice over Internet Protocol (VoIP) di lingkungan Unsoed sebagai upaya peningkatan efisiensi sumber daya", Seminar Nasional Pengembangan Sumber Daya Pedesaan dan Kearifan Lokal Berkelanjutan III, 2013.

[14] A.W.W. Nugraha, I. Setiawan, dan D. Setiawan, "Pengaruh codec terhadap unjuk kerja VoIP pada jaringan lokal Unsoed", Transmisi, vol. 17, no. 4, Oktober 2015.

[15] M. Davenport dan S. Bright, "Asterisk as a Swiss Army Knife of Telephony", Asterisk Project, 2012. [Online]. Available: https://wiki.asterisk.org/wiki/display/AST/Asterisk+as $+\mathrm{a}+$ Swiss+Army+Knife+of+Telephony

[16] B. West, J. Boteler, B. Areski, dan H. Diógenes, "FreeSWITCH Explained", FreeSWITCH, 2017. [Online]. Available: https://freeswitch.org/confluence/

[17] FreeSWITCH, "How does FreeSWITCH compare to Asterisk?", FreeSWITCH, 2008. [Online]. Available: https://-freeswitch.org/how-does-freeswitch-compareto-asterisk/

[18] Northforge, "A comparison of VoIP platforms: Asterisk vs. FreeSWITCH", Northforge, 2013. [Online]. Available: http://gonorthforge.com/acomparison-of-voip-platforms-asterisk-vs-freeswitch/

[19] D. Pocock, "Choosing between Asterisk and FreeSWITCH", in Real-Time Communications Quick Start Guide, RTC Quick Start, 2015. [Online]. Available: http://rtcquickstart.org/

[20] T. Hansmann, “Asterisk vs FreeSwitch?”, PLUG mailing list, 2013. [Online]. Available: http://plug.org/pipermail/plug/-2013-

February/029403.html

[21] J. Rosenberg, dkk., "SIP: Session Initiation Protocol", RFC 3261, 2002. [Online]. Available: https://tools.ietf.org/html/-rfc3261

[22] H. Schulzrinne, S. Casner, R. Frederick, dan V. Jacobson, "RTP: A transport protocol for real-time applications", RFC 3550, 2003. [Online]. Available: https://tools.ietf.org/-html/rfc3550

[23] T. Abbasi, S. Prasad, N. Seddigh, dan I. Lambadaris, "A comparative study of the SIP and IAX VoIP protocols", Canadian Conf. Electrical and Comput. Eng., 2005.

[24] P. Montoro dan E. Casilari, "A comparative study of VoIP standards with Asterisk", Fourth Int. Conf. on Digital Telecommunication, 2009.

[25] A.M. Ansari, M.F. Nehal, dan M.A. Qadeer, "SIPbased Interactive Voice Response system using FreeSwitch EPBX", Tenth Int. Conf. on Wireless and Optical Commun. Networks (WOCN), 2013.

[26] I. Tomičić, M. Turk, dan M. Lovrenčić, "A performance comparison of three SIP softswitches: Asterisk, FreeSWITCH, and Yate", Zbornik radova Međimurskog veleučilišta u Čakovcu, vol. 6, no. 2, 2016.

[27] ITU Telecommunication Standardization Sector (ITUT), "Mean opinion score interpretation and reporting", ITU-T Recommendation P.800.2, 2016.

[28] ETSI, "End-to-end Quality of Service in TIPHON systems; Part 2: Definition of speech Quality of Service (QoS) classes", Telecommunications and Internet Protocol Harmonization Over Networks (TIPHON) Release 3, ETSI RTS/TIPHON-05012b, 2002.

[29] ETSI, "General aspects of Quality of Service (QoS)", Telecommunications and Internet Protocol Harmonization Over Networks (TIPHON), ETSI DTR/TIPHON-05001, 1998.

[30] ITU Telecommunication Standardization Sector (ITUT), "Transmission impairments due to speech processing”, ITU-T Recommendation G.113, 2007.

[31] K.I. Park, QoS in Packet Networks. Springer, 2005.

[32] M. Voznak, M. Halas, B. Borowik dan Z. Kocur, "Delay Model of RTP Flows in Accordance with $\mathrm{M} / \mathrm{D} / 1$ and $\mathrm{M} / \mathrm{D} / 2$ Kendall's Notation", Int. J. of Mathematics and Comput. in Simulation, vol. 5, no. 3, 2011.

[33] Jaap, "What are "Difference" and "Delta" in Wireshark RTP Analysis?", Wireshark Q\&A, 2014. [Online]. Available: https://ask.wireshark.org/questions/29008/what-aredifference-and-delta-in-wireshark-rtp-analysis

[34] W.H. Purnomo, H. Susilawati, dan R.K. Noviandono, "Analisis performansi VoIP (Voice over Internet Protocol) pada jaringan WiMAX (Worldwide Interoperability for Microwave Access) di wilayah DKI Jakarta”, Jurnal Infotel, vol. 3, no. 1, Mei 2011. 